\title{
A Model to Estimate Stored Carbon in the Upland Forests of the Wanggu Watershed
}

\author{
Safril Kasim ${ }^{1}$, Aminuddin Mane Kandari ${ }^{1}$, Asramid Yasin ${ }^{1}$ \& La Ode Agus Salim Mando ${ }^{2}$ \\ ${ }^{1}$ Department of Environmental Science, Faculty of Forestry and Environmental Science, Universitas Halu Oleo, \\ Kendari, Indonesia \\ ${ }^{2}$ Department of Forestry, Faculty of Forestry and Environmental Science, Universitas Halu Oleo, Kendari, \\ Indonesia \\ Correspondence: Asramid Yasin, Department of Environmental Science, Faculty of Forestry and Environmental \\ Science, Universitas Halu Oleo, Kendari, Indonesia. E-mail: asramidyasin@uho.ac.id
}

Received: February 12, 2020

Accepted: April 14, 2020

Online Published: July 29, 2020

doi:10.5539/jsd.v13n4p47

URL: https://doi.org/10.5539/jsd.v13n4p47

\begin{abstract}
Climate change coupled with deforestation has brought about an increase in greenhouse gas emissions in the atmosphere. One way to control climate change is to reduce greenhouse gas emissions by maintaining the integrity of natural forests and increasing the density of tree populations. This research aimed to (a) identifies the density of stand trees in the upland forests of the Wanggu Watershed; (b) analyze the potential carbon stocks contained in the upstream forests of the Wanggu Watershed; (c) develop a model to estimate potential carbon stocks in the upland forests of the Wanggu Watershed. The land cover classification in this study used the guided classification with the Object-Based Image algorithm. Normalized Difference Vegetation Index (NDVI) was employed as an indicator of vegetation cover density. Field measurements were carried out by calculating the diameter of the stand trees in 30 observation plots. Field biomass values were obtained through allometric equations. Regression analysis was conducted to determine the correlation between NDVI densities and field biomass. The results showed that the best equation for estimating potential carbon stocks in the Wanggu Watershed forest area was $y=3.48$ (Exp. $7,435 \mathrm{x}$ ), with an R2 of $50.2 \%$. Potential above ground biomass carbon in the Wanggu Watershed based on NDVI values was $414,043.26$ tons in 2019 , consist of protected forest areas of $279,070.15$ tons and production forests of $134,973.11$ tons. While total above biomass carbon based on field measurement reached 529,541.01 tons, consist of protected forests of 419,197.82 tons and production forests of 110,343.20 tons.
\end{abstract}

Keywords: Wanggu watershed, model, biomass, carbon, forest, GIS

\section{Introduction}

Global climate change is a real problem and has had a wide impact on the life of organisms in general. Climate change is triggered by global warming as a result of the long-term accumulation of atmospheric pollution resulting from industrial activities, transportation, domestic activities (household), fires, and changes in forest land cover to become non-forest. The high concentration of Greenhouse Gases (GHGs) in the atmosphere has exceeded the ability of natural systems to absorb it. Some of these GHGs are Carbon Dioxide $\left(\mathrm{CO}_{2}\right)$, Methane $\left(\mathrm{CH}_{4}\right)$, Nitrogen Oxide $\left(\mathrm{N}_{2} \mathrm{O}\right)$, Hydrofluorocarbons (HFCs), Perfluorocarbons (PFCs) and Sulfur Hexafluoride $\left(\mathrm{SF}_{6}\right)$ (Efendi et al., 2012).

The existence of forests in the watershed area is a very big role as an absorber (absorption) of carbon contained in the atmosphere through photosynthesis. Furthermore, forest resources have multi-functional potential that can provide economic, environmental, and social benefits for the welfare of humanity. Therefore in the long term, the management of forest resources must be prepared to cover all of its multi-functional potentials, so that be able in transforming economic, environmental, and social potentials into tangible benefits for the community.

Rapid land-use change in Indonesia is one of the national phenomena that have an impact on environmental degradation. In watershed ecosystems, changes in land use especially forest land use to non-forest designation have led to a decline in the function of watershed ecosystems, among others: increased surface runoff, decreased infiltration and percolation capacity, increased levels of erosion and river sedimentation hazards, increased distribution critical land and decreased land productivity in the watershed. Some research results indicate that 
changes in land use in the watershed become a major factor in the degradation of the watershed ecosystem. Changes in forest land use in the Baubau watershed have led to decreased hydrological functions of the watershed, including fluctuations in maximum and minimum discharges, increased levels of the hazard of erosion and river sedimentation (Kasim and Midi, 2014). The dynamic land-use change analysis in the Wanggu Watershed during the last 20 (twenty) years (1998-2018) showed that an average decline in forest land area was 329.84 ha year${ }^{1}(1.08 \%)$, which was at the same period, shrubs, dryland agriculture, settlements, and bare land increased by 124.92 ha year $^{-1}(0.41 \%), 109.24$ ha year $^{-1}(0.36 \%), 40.85{\text { ha } y^{-1}(0.13 \%) \text { and } 70.06 \text { ha year }}^{-1}(0.23 \%)$ respectively of the total area of the watershed (Kasim et al., 2020).

Deforestation and forest degradation in developing countries and industrial emissions from developed countries are the cause of increased greenhouse gas emissions in the atmosphere. Data on total deforestation from 10 developing countries is around 8.22 million ha, of which 1.87 million ha of this area is deforestation from Indonesia (FAO, 2006). One way to control climate change is to reduce greenhouse gas (CO, $\mathrm{CH}$, and $\mathrm{NO}$ ) emissions by maintaining the integrity of natural forests and increasing the density of tree populations. Plants both inside and outside the forest area absorb carbon dioxide $\left(\mathrm{CO}_{2}\right)$ from the air through photosynthesis and store it as organic material in plant organs (Hairiah et al., 2011). The amount of organic material stored in plant organs per unit area and per unit time is a staple of forest productivity (Heriansyah, 2005). A high density of trees will cause the amount of $\mathrm{CO}_{2}$ uptake by trees will also be higher (Wahyuni, 2016). To this point, the conversion of forests causes a decrease in the amount of stored carbon. The amount of stored carbon can describe how much $\mathrm{CO}_{2}$ is absorbed by plants for later processing through photosynthesis. The results of photosynthesis are then distributed to all parts of the plant and eventually become biomass. So, by calculating plant biomass in a field can describe how much $\mathrm{CO}_{2}$ is absorbed by these plants (Wahyuni, 2016). Furthermore, Hairiah and Rahayu (2007) stated that unspoiled forest with a diversity of long-lived plant species and litter that is a place to store the highest carbon stock (C) compared with forests that have been converted into plantation or agricultural land.

Concerning the concept of controlling global climate change through the Reducing Emissions from Deforestation and Forest Degradation (REDD) scheme which aimed at knowing the magnitude of carbon stock changes due to forest degradation and deforestation (Hairiah et al., 2011), thus the implementation of this program should be measurable, reportable, and verifiable (MRV). To this end, the REDD scheme should provide a framework to monitor changes in forest carbon stocks and flows, to report these changes in a transparent and timely manner, and to examine carbon stocks estimation through independent third parties (Herold and Skutsch, 2009).

Field measurement of carbon potential has been done a lot, employing either destructive or non-destructive method. This is very effective and has a high degree of accuracy, but is considered very expensive and requires a relatively long time, especially for such width areas as a watershed ecosystem-based. The development of remote sensing technology, both from spatial and temporal resolution, can be used to effectively and efficiently analyze carbon potential stocks in vegetation.

Based on the description above, it is necessary to develop an estimation model of carbon potential stocks in the forested lands at the watershed ecosystem scale using Remote Sensing and GIS tools. The research aimed to determine the density of vegetation trees in the upland forests, to estimate the potential field biomass and carbon stocks contained in the upstream forests, and to create a model for estimating potential carbon stocks in the upland forests of the Wanggu Watershed.

\section{Method}

\subsection{Time and Area Setting}

This research was effectively carried out from May to December 2019 in the upland forests of the Wanggu Watershed, Southeast Sulawesi Province Indonesia. The Wanggu Watershed is located at the "foot" of Sulawesi Island, Eastern Indonesia, and is part of the Wallace Ecosystem. This watershed has an area of 30,599.45 ha and connects 2 autonomous regions, namely Kendari City and South Konawe District. Astronomically, this watershed is located at $03^{0} 58^{\prime} 00^{\prime \prime}$ - $04^{0} 30^{\prime} 00^{\prime \prime}$ latitude and $122^{0} 23^{\prime} 40^{\prime \prime}$ - $122^{0} 33^{\prime} 10^{\prime \prime}$ longitude. Based on administrative boundaries, the North of the watershed is bordered by Mandonga Subdistrict of Kendari City, the South is bordered by South Konawe Regency, the East is bordered by Poasia Regency, Kendari City, and North Moramo, South Konawe Regency, while the west is bordered by Konawe and South Konawe Regencies.

\subsection{Materials and Tools}

The materials in this study were all stands (sapling, poles, and trees) found in the 30 observation units of the upland forests of the Wanggu Watershed and Landsat 8 images in 2019 from USGS (The United States Geological Survey). The tools used were laptops that have Microsoft Office programs (Microsoft Word, Microsoft Excel), SAGA GIS 
and Arc Map version 10.4.1, Global Positioning System (GPS), camera, compass, roll meter, measuring tape, tallysheet, and stationery.

\subsection{Population and Samples}

The population was all stands in protected and production forests in the Wanggu Watershed covering an area of 6,983.98 ha (Forest Area Map, 2014). The samples were vegetation trees at the various growth rates of stakes, poles, and trees contained in the 30 observation plots, with each plot size of $20 \mathrm{~m}$ x $20 \mathrm{~m}$ or 0.04 ha. The basis for determining the observation plots used following the Indonesian National Standard on Measurement and Calculation of Carbon Reserves - Field Measurement for Estimating Forest Carbon Reserves (BSN, 2011). The sample placement was purposively conducted by considering the representation of the density of the stands and the distribution of trees found in the study area. Field data retrieval was carried out by a non-destructive method by measuring the size of the stand trees circumference and species identification.

\subsection{Data Types and Sources}

The types and sources of data in this study can be seen in Table 1:

Table 1. Types and data sources

\begin{tabular}{ll}
\hline Data Type & Data Source \\
\hline 1. Primary Data: & \\
a. Diameter Breast Height $(\mathrm{dbh} / \mathrm{cm})$ & Field measurement \\
b. Species Identification & Field measurement \\
c. Land cover map & Analysis of Geographic Information System (GIS) \\
d. Vegetation density map & Analysis of Geographic Information System (GIS) \\
2. Secondary Data: & \\
a. Demographic data & Central Statistics Agency \\
b. Climatic data & Meteorological, Climatological, and Geophysical Agency (BMKG) \\
c. Administrative map & Geospatial Information Agency \\
d. Topographic maps & Digital Data Elevation Model (DEM) \\
f. Map of forest area & Ministry of Environment and Forestry \\
\hline
\end{tabular}

\subsection{Method of Collecting Data}

\subsubsection{Literature Review}

This method is used to explore the literature from various sources that are relevant to the research objectives, whether in the form of research reports, documents from the local and national government, spatial data, or other sources.

\subsubsection{Field Survey}

The survey is a method of collecting data by making direct observations and measurements of the objects under study, the data obtained in the form of vegetation types, the circumference and diameter of the vegetation in the study area.

\subsection{Data Analysis}

\subsubsection{Vegetation Density}

Vegetation density was analyzed through spatial data analysis of Landsat 8 images using the NDVI (Normalized Difference Vegetation Index) algorithm which is a calculation of visible light (RED) and near-infrared (Near Infrared) reflected by vegetation. Both data were obtained through the recording of Landsat 8 satellite imagery in 2019. Landsat 8 satellites have 11 channels/bands, each of these channels has different spatial resolution and wavelength. The canal/band used in the NDVI algorithm is channel/band 5 (Near Infra-Red) and channel/band 4 (RED). According to Green et al., (2000), NDVI values can be analyzed using the equation: 


$$
\mathrm{NDVI}=(\mathrm{NIR}-\mathrm{RED}) /(\mathrm{NIR}+\mathrm{RED})
$$

Note. NIR=near infrared band; $\mathrm{RED}=$ red band

\subsubsection{Field Stored Biomass Estimation}

Estimation of the potential biomass was analyzed using allometric equations that had been developed by previous researchers. Allometrics is a direct approach to estimating aboveground biomass from a tree/forest (IPCC, 2003). The allometric equation used in this study in detail can be seen in Table 2.

Table 2. Allometric equations which are used for guessing values stored biomass

\begin{tabular}{cc}
\hline Category Biomass & Equations Allometric \\
\hline Branched trees & $\mathrm{BK}=0.11 p\left(\mathrm{D}^{2,62}\right)$ \\
Unbranched trees & $\mathrm{BK}=0.25 \pi p \mathrm{H}^{\left(\mathrm{D}^{2}\right)}$ \\
\hline
\end{tabular}

Note. $\mathrm{BK}=$ biomass $\left(\mathrm{kg}_{\text {tree }}{ }^{-1}\right) ; \mathrm{D}=\mathrm{dbh}(\mathrm{cm}) ; \mathrm{H}=$ tree height $(\mathrm{cm}) ; p=$ wood density $\left(\mathrm{gr} \mathrm{cm}^{-3}\right)$; wood $p=0.7 \mathrm{gr} \mathrm{cm}^{-3}$

Source: (Ketterings, 2001; Hairiah and Rahayu, 2007).

\subsubsection{Potential Stored Carbon}

According to Hairiah and Rahayu (2007), the carbon concentration contained in organic matter is $47 \%$, so to estimate the amount of stored carbon by multiplying 0.47 by the value of biomass. Therefore the potential for carbon stocks in forests can be analyzed by the following equation:

$$
\mathrm{C}=\mathrm{W} \times 0.47
$$

Note. $\mathrm{C}=$ carbon; $\mathrm{W}=$ biomass

\subsubsection{Biomass Estimation Model}

The statistical analysis was carried out consisting of tests of normality, correlation, regression, and validity of the models to develop stored carbon estimation models. The statistical analysis was conducted using SPSS software. This analysis aimed to find the relationship between biomass field and biomass image data.

The normality test was carried out using the Kolmogorov-Smirnov method to determine the distribution of the independent variable (vegetation index) to the dependent variable (biomass) whether it spreads normally or not. Regression models can be categorized as the appropriate models if they have residual values that are normally distributed in the form of a straight line (Draper and Smith, 1992). If the p-value is greater than $\alpha$, then $\mathrm{H}_{0}$ would be accepted. A correlation test was conducted using the Pearson Method to analyze the relationship between the independent variable (NDVI value) and the dependent variable (field biomass). Regression coefficient analysis was undertaken to examine the level of significance of the independent variable to the dependent variable, if the value of sig $<0.05$ then the influence of the independent variable has been significant so that the regression model can be applied, whereas if sig $>0.05$, it means that the regression model cannot be used. While the coefficient of determination value $(\mathrm{R})$ is also analyzed to determine the best model applied.

\section{Results and Discussion}

\subsection{Vegetation Density in the Upland Forests of the Wanggu Watershed}

Vegetation density was analyzed using NDVI (Normalized Difference Vegetation Index) from Landsat 8. NDVI image data which is a calculation of visible light and near-infrared reflected by vegetation. NDVI values less than 0 indicate objects of water or vacant land, while NDVI values greater than 0 indicate the presence of high photosynthetic activity or agricultural lands (Meneses 2011). The results of the NDVI analysis are digital numbers ranging from -1 to 1 (Suyadi et al., 2013), which the higher the NDVI value, the higher the density of vegetation.

The results of the NDVI analysis in the upland forests of the Wanggu Watershed show that the NDVI values range from 0.08 to 0.57 , the value is then divided into 3 density classes using the natural breaks method which is low, medium, and high. In detail, the level of vegetation density of forest areas in the Wanggu Watershed, both in protected and production forests as shown in Table 3. 
Table 3. Vegetation density in the upland forests of Wanggu watershed based on NDVI values

\begin{tabular}{cccccccc}
\hline & \multicolumn{4}{c}{ Forest Type } & \multicolumn{3}{c}{ Area } \\
\cline { 2 - 5 } Vegetation Density Class & \multicolumn{2}{c}{ Protected Forest } & \multicolumn{2}{c}{ Production Forest } & \multirow{2}{*}{ Ha } & \multirow{2}{*}{$\%$} \\
\cline { 2 - 5 } & Ha & $\%$ & Ha & $\%$ & & 1.30 \\
Low & 30.41 & 0.44 & 60.48 & 0.83 & 90.90 & 4.89 \\
Medium & 122.92 & 1.76 & 218.72 & 3.13 & 341.64 & 93.81 \\
High & $4,553.94$ & 65.21 & $1,997.49$ & 28.60 & $6,551.43$ & 100.00 \\
\hline Total & $4,707.28$ & 67.40 & $2,276.69$ & 32.60 & $6,983.97$ & \\
\hline
\end{tabular}

Table 3 shows that overall vegetation density in the upland forests of the Wanggu Watershed is dominated by highdensity class, which covers $6,551.43$ ha or $93.81 \%$ of the total area of the watershed, followed by medium and low-density classes with an area of 341.64 ha (4.89\%) and 90.90 ha (1.30\%) respectively. A high-class density also dominates both at protected and production forest which covers 4,553.94 ha (65.21\%) and 1,997.49 ha (28.60\%). The spatial distribution of vegetation density of upland forests in the Wanggu Watershed is displayed in Fig. 1.

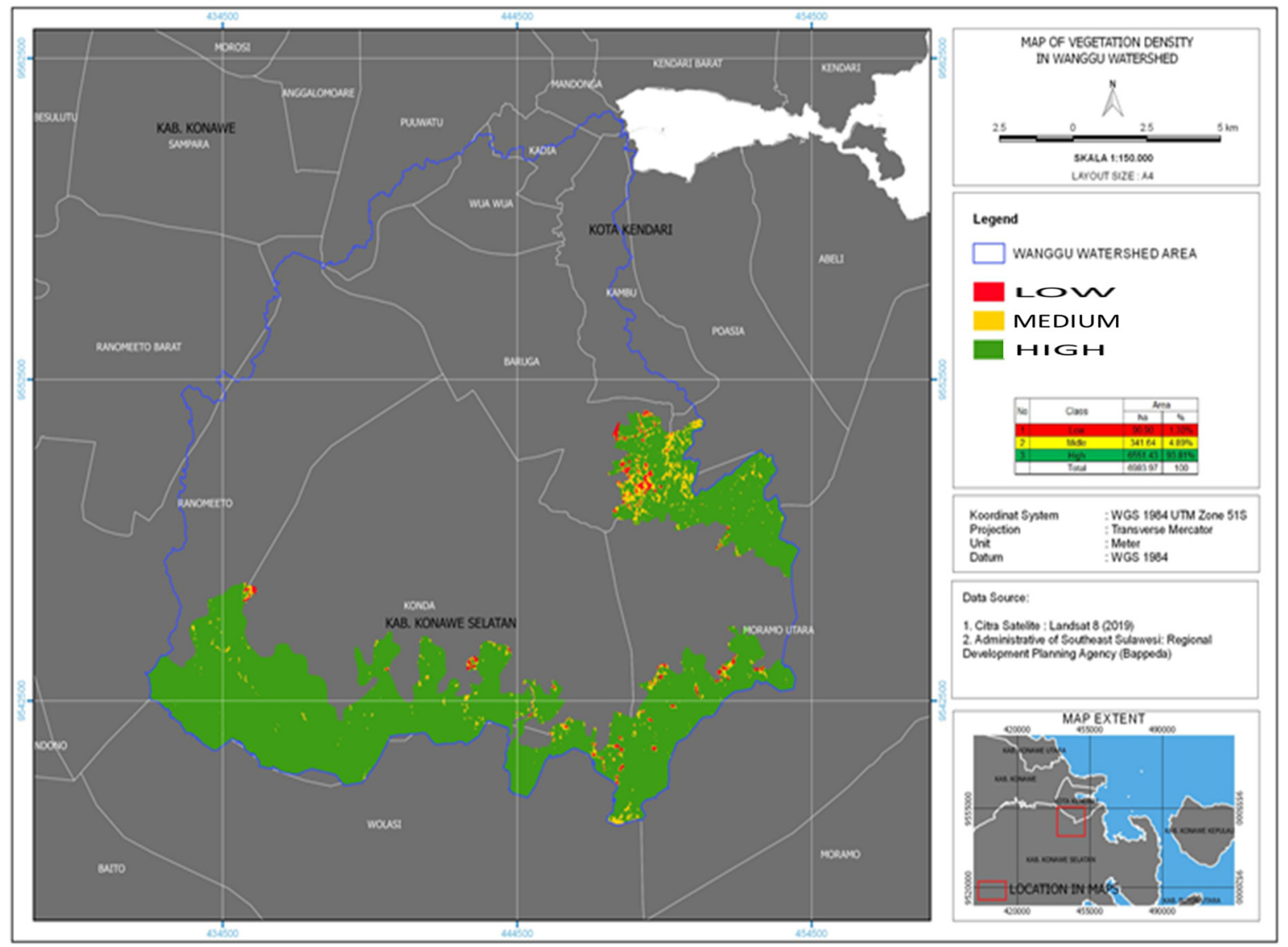

Figure 1. Map of vegetation density of upland forests in the Wanggu watershed

\subsection{Stored Biomass Estimation using Allometric Equation (Field Survey)}

\subsubsection{Relationship between Stand Trees Diameter and Biomass Value}

High or low biomass value in each plot is determined by the diameter of the stand trees. A diameter breast height (dbh) of each tree is measured in each observation plots. Data analysis shows that the value of biomass has a positive correlation with the diameter of the stand trees in each observation plot. The relationship between the biomass value and the diameter of the stand trees is represented in Fig. 2. 


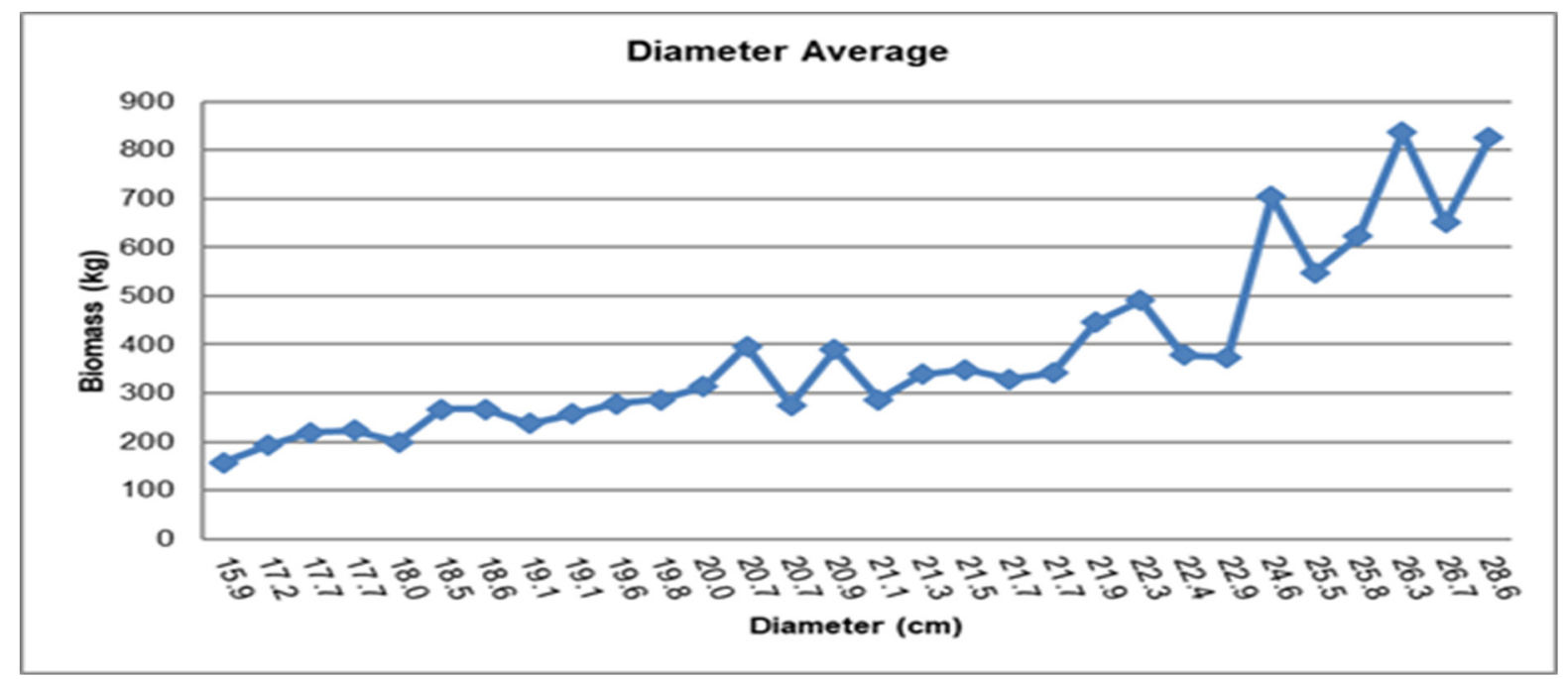

Figure 2. The relationship between stand trees diameter $(\mathrm{cm})$ and the biomass value $(\mathrm{kg})$ of upland forests in the Wanggu watershed

Figure 2 shows that the relationship between diameter and biomass produced is positively correlated in the study area. The greater the diameter of the plant, the greater the biomass, and vice versa. The amount of biomass is closely related to the process of photosynthesis, biomass increases because plants absorb $\mathrm{CO}_{2}$ from the air and convert it into organic compounds. This shows that diameter growth is related to the growth of tree biomass and also related to the amount of carbon stored in vegetation. Most of this biomass is found in tree trunks. The tree component has the largest percentage is the trunk which is a woody part and the largest storage site for photosynthesis reserves for growth (Syam'ani et al., 2012). Moreover, Chairul et al., (2016) stated that the carbon content of a forest is determined by biomass, whereas the amount of biomass is affected by the diameter of the trunk, tree height, density, and density of plants on the land.

\subsubsection{Carbon Estimation Based on Field Biomass Values}

The measurement of tree biomass has been carried out employing a non-destructive approach. Tree biomass (in dry weight) was analyzed using an allometric equation based on a wood density and a stem diameter as high as $1.3 \mathrm{~m}$ above ground level both for branch trees and unbranched trees. The results of biomass analysis (Fig. 3) were multiplied by 0.47 , this is because the carbon content of organic material is $47 \%$ of the total biomass (Hairiah and Rahayu, 2007). The results of stored carbon analysis both in protected and production forests of the Wanggu Watershed is shown in Table 4.

Table 4. Stored carbon values in the protected and production forest of the Wanggu watershed in 2019

\begin{tabular}{ccc}
\hline Forest Status & Average Carbon $\left(\right.$ ton $\left.\mathrm{ha}^{-1}\right)$ & Total Carbon Stored (ton) \\
\hline Protected forest & 89.05 & $419,197.82$ \\
Production forest & 48.46 & $110,343.20$ \\
\hline & Total & $529,541.01$ \\
\hline
\end{tabular}

Table 4 shows that the average stored carbon in the protected forest is higher almost two times than the production forest, which achieves 89.05 and 48.46 tons $\mathrm{C} \mathrm{ha}^{-1}$ respectively. The total above-ground carbon in the upland forest of the Wanggu Watershed reaches 529,541.01 tons C consisting of 419,197.82 tons $C$ in the protected forests and 110,343.01 tons $\mathrm{C}$ in the production forests. Protected forest areas following its designation are it the forest areas that have the function of protecting live support systems, regulating water system, supplying oxygen need for living creatures around. The use of protected forest areas in the Wanggu Watershed is directed to research and development needs, limited ecotourism, and the use and the development of environmental services and nontimber forest products. Whereas production forests are forest areas that are intended to fulfill the needs of woods, both for building materials and furniture e, and others. So that, based on its designation forest stands in these areas 
can periodically be harvested under the principles of sustainable forest management. Idris et al., (2015) stated that carbon is stored differently for different types of forests. Changes in the composition and structure of forest stands affect carbon stocks (Idris, et al., 2015). Natural protected forest with a diversity of long-lived plant species and litter that is a place to store the highest carbon stock (C) when compared with production forests or agricultural land (Hairiah and Rahayu, 2007). Mode et al., (2009) stated that natural forests, consisting of various types of plants, can absorb stored carbon more than agricultural land and plantation forests.

The aboveground carbon value of upland forests in the Wanggu Watershed is relatively lower than aboveground carbon stocks in various land cover classes in Bogor. Masripatin et al., (2010) stated that aboveground carbon stocks in various land cover classes of natural forests in Bogor, including dipterocarp natural forests with carbon reserves of 204.9 - 264.7 tons $\mathrm{C} \mathrm{ha}^{-1}$, lowland natural forests which are 230.1-264.7 tons $\mathrm{C}^{-1}$, highland primary natural forests which are 103.1 tons $\mathrm{C} \mathrm{ha}^{-1}$. A comparison of the amount of carbon stored in the upland forests of the Wanggu Watershed is displayed in Fig. 3.

\section{Percentage of Carbon (c) Reserves in Wanggu Watershed}

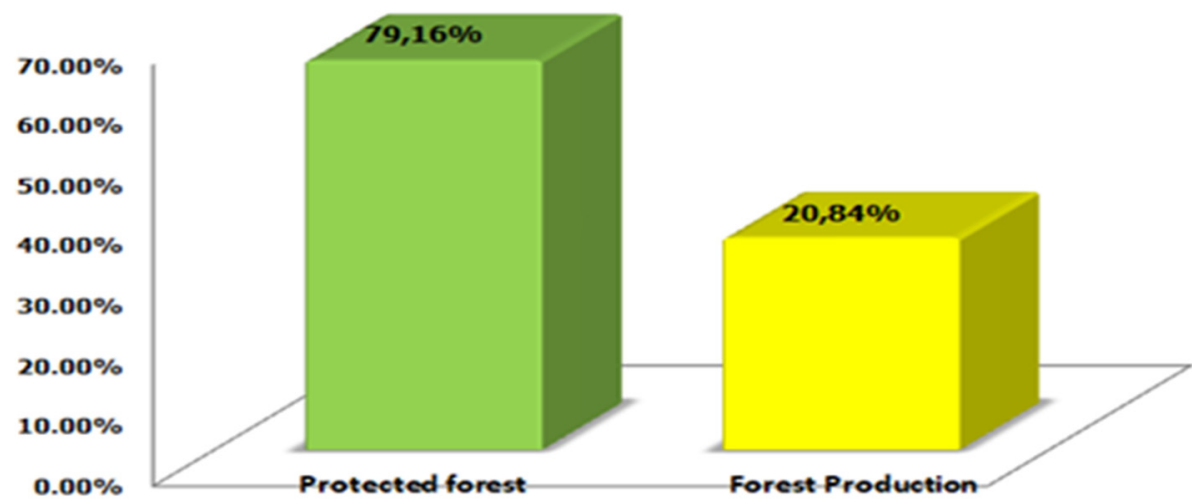

Figure 3. Comparison of carbon quantities stored in the Wanggu watershed forest area

\subsection{Carbon Stored Estimation Model}

\subsubsection{Normality Test}

The normality test was carried out using the Kolmogorov Smirnov method to determine the distribution of NDVI values obtained through image interpretation and biomass content from 30 field observation plots. The results of the normality test showed that the data of the independent variables (NDVI values) and the dependent variables (biomass value) were not normally distributed, where there were outliers of data in 13 observation plots. Therefore, a reduction in 13 sample plots was made which shows the outliers of the data. To do so, the distribution of values is spread normally.

\subsubsection{Correlation Test}

A correlation test was conducted using the Pearson Method to analyze the relationship between the independent variable (NDVI value) and the dependent variable (field biomass). The coefficient of correlation value (r) indicates the strength and direction of the relationship between variables in a regression model. The correlation value interval ranges from -1 to 1 . When the coefficient of the correlation value is negative, meaning that the relationship between the two variables is inversely proportional, ie if one of the variable values decreases, then the other variables will increase. Conversely, if the coefficient of the correlation value is positive showing the relationship between the two variables is directly proportional, that is if the value of one variable increases, then the other variable will also increase. If the coefficient of the correlation value is 0 , the two variables do not correlate to each other. When the coefficient of the correlation value is getting closer to 1 , then the stronger the relationship between two variables (NDVI and biomass values) in this regression model.

In addition to seeing the coefficient of the correlation value, decision making in correlation analysis can also be done by looking at the significant value in the SPSS output. If the significance value $<0.05$ then the variables analyzed are correlated to each other, conversely if the significance value $>0.05$ the variables do not correlate. The results of the correlation analysis in this study show that there is a significant correlation between NDVI and biomass as shown in Table 5. 
Table 5. The coefficient of the correlation value

\begin{tabular}{ccccccc}
\hline & \multicolumn{3}{c}{ NDVI } & \multicolumn{3}{c}{ Biomassa } \\
\cline { 2 - 7 } & $\begin{array}{c}\text { Pearson } \\
\text { Correlation }\end{array}$ & $\begin{array}{c}\text { Sig. (2- } \\
\text { Tailed) }\end{array}$ & $\mathrm{N}$ & $\begin{array}{c}\text { Pearson } \\
\text { Correlation }\end{array}$ & $\begin{array}{c}\text { Sig. (2- } \\
\text { Tailed) }\end{array}$ & $\mathrm{N}$ \\
\hline NDVI & 1 & & 17 & $0.823^{* *}$ & 0.000 & 17 \\
Biomassa & $0.823^{* *}$ & 0.000 & 17 & 1 & & 17 \\
\hline
\end{tabular}

Note. Correlation is significant at the 0.01 level (2-tailed)

Table 5 shows that the coefficient of the correlation value is $r=0.823$, and the significant value is ( $p$-value) $=$ 0.000 that is less than $\alpha=0.005$. This indicates that based on correlation analysis, there is a relationship between $\mathrm{y}$ variable (field biomass) and $\mathrm{x}$ variable (NDVI). The positive value of the correlation analysis indicates that the relationship between the two variables is directly proportional which means if one variable value increases, then another variable value will increase and vice versa (Walpole, 1995; Wijayadi, 2017).

\subsubsection{Coefficient Determination Analysis}

The coefficient of the correlation value does not always indicate a causal relationship between the two variables, therefore, the coefficient of determination value $(\mathrm{R})$ is also used to determine the best model applied. The R-value will indicate the percentage deviation of the dependent variable (biomass) that can be explained by the independent variable (NDVI) in a regression model. The higher the value of $\mathrm{R}$ in a regression model, the better the model is used for estimating biomass.

The coefficient of determination value was analyzed on each developed model, namely a linear regression model, an exponential regression model, and a quadratic regression model. The coefficient of determination value of each model can be seen in Table 6 .

Table 6. The coefficient of determination value

\begin{tabular}{ccc}
\hline Regression Model & $\mathrm{R}$ & R Square \\
\hline Linear & 0.568 & 0.322 \\
Quadratic & 0.658 & 0.433 \\
Exponential & 0.708 & 0.502 \\
\hline
\end{tabular}

Table 6 depicts that each regression model has a different coefficient of determination value. The coefficient of determination value of the linear regression is 0.568 . This means that $56.8 \%$ of the dependent variable (biomass) can be explained by the independent variable (NDVI) in a linear regression model and $32.2 \%$ is explained by other factors that were not analyzed in this equation. Furthermore, $65.8 \%$ of the dependent variable (biomass) can be explained by the independent variable (NDVI) in a quadratic regression model, and $43.3 \%$ is determined by other factors that were not examined, while the exponential regression model has the highest percentage of $70.8 \%$ of the dependent variable (biomass) can be explained by the independent variable (NDVI). The results of the coefficient of determination analysis show that the exponential regression model is the best model that can explain the relationship between the dependent variable (biomass) and the independent variable (NDVI) in this study.

\subsubsection{Coefficient Regression Analysis}

The coefficient of regression analysis was carried out to determine the coefficient of regression value used in the allometric model for estimating biomass using NDVI values. ANOVA test is then performed to determine the level of significance of the influence of independent variables on the dependent variable, if the value of sig $<0.05$ then the influence of the independent variable is significant so that the regression models can be applied, whereas if sig $>0.05$ then the regression models cannot be used.

T-test was conducted to determine the coefficient of the independent variables that affect the dependent variable with the criterion p-value $<\alpha$ at the $95 \%$ confidence level $(\alpha=0.005)$. This T-test also aims to analyze the significance of constants and the coefficients of the independent variables in the regression model. A good regression model has a constant value and variable coefficient with sig $<0.05$ and if the value of sig $>0.05$ then the constant or the coefficient of the variable cannot be used because it is not significant. The biomass estimation 
model in this study consists of a linear regression model, a quadratic regression model, and an exponential regression model. The results of the coefficients of regression analysis using SPSS are presented in Table 7.

Table 7. The results of coefficient regression analysis

\begin{tabular}{|c|c|c|c|c|c|c|}
\hline \multirow{2}{*}{$\begin{array}{l}\text { Regression } \\
\text { Model }\end{array}$} & \multicolumn{3}{|c|}{ Constanta Regression } & \multirow{2}{*}{ F-Calculate } & \multirow{2}{*}{$\mathrm{T}$} & \multirow{2}{*}{ Sig. } \\
\hline & a & $\mathbf{b}$ & c & & & \\
\hline Linear & -373.02 & $1,072.65$ & - & 7.14 & 2,672 & 0.017 \\
\hline Exponential & 3.48 & 7.43 & - & 15.10 & 3,887 & 0.001 \\
\hline Quadratic & $2,404.42$ & $-11,185.26$ & $13,249.40$ & 5.33 & $-1,502$ & 0.019 \\
\hline
\end{tabular}

Table 7 shows that the regression models are statistically very significant with $p$-value $<\alpha$, where $\alpha=0.005$. Based on the results of the coefficient regression analysis, the three regression models can be used as estimation models of the potential of standing forest biomass, both in protection and production forests of the Wanggu Watershed.

\subsubsection{Formulation of Biomass Estimation Model}

The regression model used to study the relationship between field biomass values and NDVI values is a linear and non-linear regression model. The non-linear regression model consists of quadratic regression and exponential regression models. The use of the non-linear regression model in this study aims to analyze the characteristics of NDVI and field biomass that have a value limit (maximum value). So the regression equations of the 3 models used are:

$$
\begin{array}{ll}
\text { Linear regression } & : \mathrm{Y}=\mathrm{a}+\mathrm{bx} \\
\text { Exponential regression } & : \mathrm{Y}=\mathrm{a} \operatorname{expbx} \\
\text { Quadratic regression } & : \mathrm{Y}=\mathrm{a}+\mathrm{bx}+\mathrm{cx}^{2}
\end{array}
$$

Note. $\mathrm{Y}=$ dependent variable (biomass/ton $\mathrm{ha}^{-1}$ ); $\mathrm{a}, \mathrm{b}, \mathrm{c}=$ regression coefficient; $\mathrm{x}=$ independent variable (NDVI)

The best estimator model for each NDVI value can be determined based on the value of $r$ (coefficient of correlation value), the value of R2 (coefficient of determination value), the value of ANOVA test and T-test, so that the allometric models of the relationship between the stand trees biomass and NDVI values can be formulated as shown in Table 8:

Table 8. Coefficient of correlation values (R) and coefficient of determination value (R2)

\begin{tabular}{cllc}
\hline Model & \multicolumn{1}{c}{ Equation } & \multicolumn{1}{c}{$\mathrm{R}$} & $\mathrm{R} 2$ \\
\hline Linear & $-373,025-(1,072.65 \mathrm{x})$ & 0.568 & 0.322 \\
Quadratic & $2,404.42-(-11,185.26 \mathrm{x})-13,249.40 \mathrm{x}^{2}$ & 0.658 & 0.433 \\
Exponential & $3.48($ Exp. 7,435x) & 0.708 & 0.502 \\
\hline
\end{tabular}

Table 8 shows that the exponential regression model is a model that has a higher coefficient of correlation value (R) and Coefficient of Determination Value (R2) compared to the quadratic and linear regression models. The Rvalue of the exponential model is 0.708 , which means that there is a relationship between the value of the image and field biomass of $70.8 \%$. The higher the value of $\mathrm{R}$ in a regression model, the better the model is used as the biomass estimation model. The R2 value of the exponential regression model of 0.502 , this value indicates that the independent variable affects the dependent variable by $50.02 \%$ and the remaining $49.98 \%$ is another variable that is not observed in this study.

Decision making of the most appropriate model used is also based on the potential value of biomass from some regression models that are closer to the value of biomass from field measurements. In detail, the potential value of biomass in each observation plot using estimator models is depicted in Table 9. 
Table 9. Biomass stored value in each observation plot using estimator models

\begin{tabular}{|c|c|c|c|c|c|}
\hline \multirow{2}{*}{ Plot } & \multirow{2}{*}{ NDVI } & \multirow{2}{*}{$\begin{array}{l}\text { Field Biomass } \\
\quad\left(\text { tons } \mathrm{ha}^{-1}\right)\end{array}$} & \multicolumn{3}{|c|}{ Image Biomass (tons ha ${ }^{-1}$ ) } \\
\hline & & & Quadratic & Linear & Exponential \\
\hline 1 & 0.504 & 375.07 & 132.62 & 167.59 & 147.91 \\
\hline 2 & 0.505 & 150.98 & 134.80 & 168.66 & 149.02 \\
\hline 3 & 0.522 & 111.54 & 175.97 & 186.90 & 169.10 \\
\hline 4 & 0.539 & 289.89 & 224.80 & 205.13 & 191.88 \\
\hline 5 & 0.517 & 198.49 & 163.07 & 181.54 & 162.93 \\
\hline 6 & 0.473 & 90.10 & 78.07 & 134.34 & 117.47 \\
\hline 7 & 0.513 & 82.12 & 153.22 & 177.25 & 158.15 \\
\hline 8 & 0.435 & 47.08 & 45.96 & 93.58 & 88.55 \\
\hline 9 & 0.471 & 58.60 & 75.43 & 132.19 & 115.73 \\
\hline 10 & 0.461 & 77.10 & 63.80 & 121.47 & 107.44 \\
\hline 11 & 0.412 & 45.42 & 45.11 & 68.91 & 74.64 \\
\hline 12 & 0.51 & 81.18 & 146.11 & 174.03 & 154.66 \\
\hline 13 & 0.544 & 140.94 & 240.62 & 210.50 & 199.15 \\
\hline 14 & 0.528 & 155.66 & 192.33 & 193.33 & 176.81 \\
\hline 15 & 0.505 & 114.78 & 134.80 & 168.66 & 149.02 \\
\hline 16 & 0.532 & 337.46 & 203.77 & 197.63 & 182.15 \\
\hline 17 & 0.519 & 309.09 & 168.15 & 183.68 & 165.37 \\
\hline 18 & 0.538 & 356.55 & 221.72 & 204.06 & 190.46 \\
\hline 19 & 0.537 & 149.46 & 218.66 & 202.99 & 189.05 \\
\hline 20 & 0.548 & 270.38 & 253.75 & 214.79 & 205.16 \\
\hline 21 & 0.367 & 71.62 & 83.98 & 20.64 & 53.41 \\
\hline 22 & 0.434 & 92.72 & 45.63 & 92.51 & 87.90 \\
\hline 23 & 0.502 & 85.12 & 128.33 & 165.45 & 145.73 \\
\hline 24 & 0.523 & 155.76 & 178.63 & 187.97 & 170.36 \\
\hline 25 & 0.424 & 89.34 & 43.80 & 81.78 & 81.60 \\
\hline 26 & 0.486 & 51.91 & 97.85 & 148.28 & 129.39 \\
\hline 27 & 0.367 & 64.24 & 83.98 & 20.64 & 53.41 \\
\hline 28 & 0.521 & 101.12 & 173.34 & 185.83 & 167.84 \\
\hline 29 & 0.531 & 207.82 & 200.87 & 196.55 & 180.80 \\
\hline \multirow[t]{2}{*}{30} & 0.519 & 122.79 & 168.15 & 183.68 & 165.37 \\
\hline & Total & 4,484 & 4,277 & 4,671 & 4,330 \\
\hline
\end{tabular}

Table 9 shows that the total potential biomass in 30 observation plots using an exponential regression model of 4,330 tons, this value is closer to the estimated field biomass value of 4,484 tons compared to the other estimation models (linear and quadratic regression models). So the estimation model that can be applied to estimate aboveground biomass potential in the upland forests of the Wanggu Watershed is an exponential regression model with the equation $\mathrm{y}=3.48$ (Exp. 7,435x).

\subsection{Carbon Stored Estimation of Upland Forests in the Wanggu Watershed Using NDVI Values}

The selected biomass estimation model was then used to calculate the potential value of carbon stocks contained in the upland forests of the Wanggu Watershed. The potential value of above-ground carbon using the selected model of 414,043.26 tons in 2019. The value is obtained based on the estimation of carbon stocks from NDVI 
values in Landsat 8 image data. The spatial distribution of carbon stocks in upland forest areas in the Wanggu Watershed is represented on a map of the distribution of potential carbon stock values (Fig. 4). Potential carbon stock values range from 6.7 tons $\mathrm{ha}^{-1}$ to 256.42 tons $\mathrm{ha}^{-1}$ which are divided into 3 classes based on the natural breaks method. In detail, classes of potential values of forest carbon stocks are shown in Table 10.

Table 10. Class of potential stored carbon values in the upland forests of the Wanggu watershed

\begin{tabular}{ccc}
\hline Carbon Reserve & Class Interval (ton ha ha $^{-1}$ & Area (ha) \\
\hline Low & $6.7-67.25$ & 266.13 \\
Medium & $67.26-96.10$ & 723.22 \\
High & $96.11-256.42$ & $5,994.63$ \\
\hline & & $6,983.98$ \\
\hline
\end{tabular}

Furthermore, the results of data analysis show that protected forest areas have a potential carbon stock value of $279,070.15$ tons, followed by production forest areas of 134,973.11 tons. Total potential carbon stock in the upland forests of the Wanggu Watershed reaches 414,043.26 tons (Table 11).

Table 11. Spatial distribution of stored carbon value in the upland forests of the Wanggu watershed

\begin{tabular}{ccc}
\hline Forest Status & Stored Carbon Value & Area (ha) \\
\hline Protection forest & $279,070.15$ & $4,707.28$ \\
Production forest & $134,973.11$ & $2,276.69$ \\
\hline Total & $414,043.26$ & $6,983.98$ \\
\hline
\end{tabular}

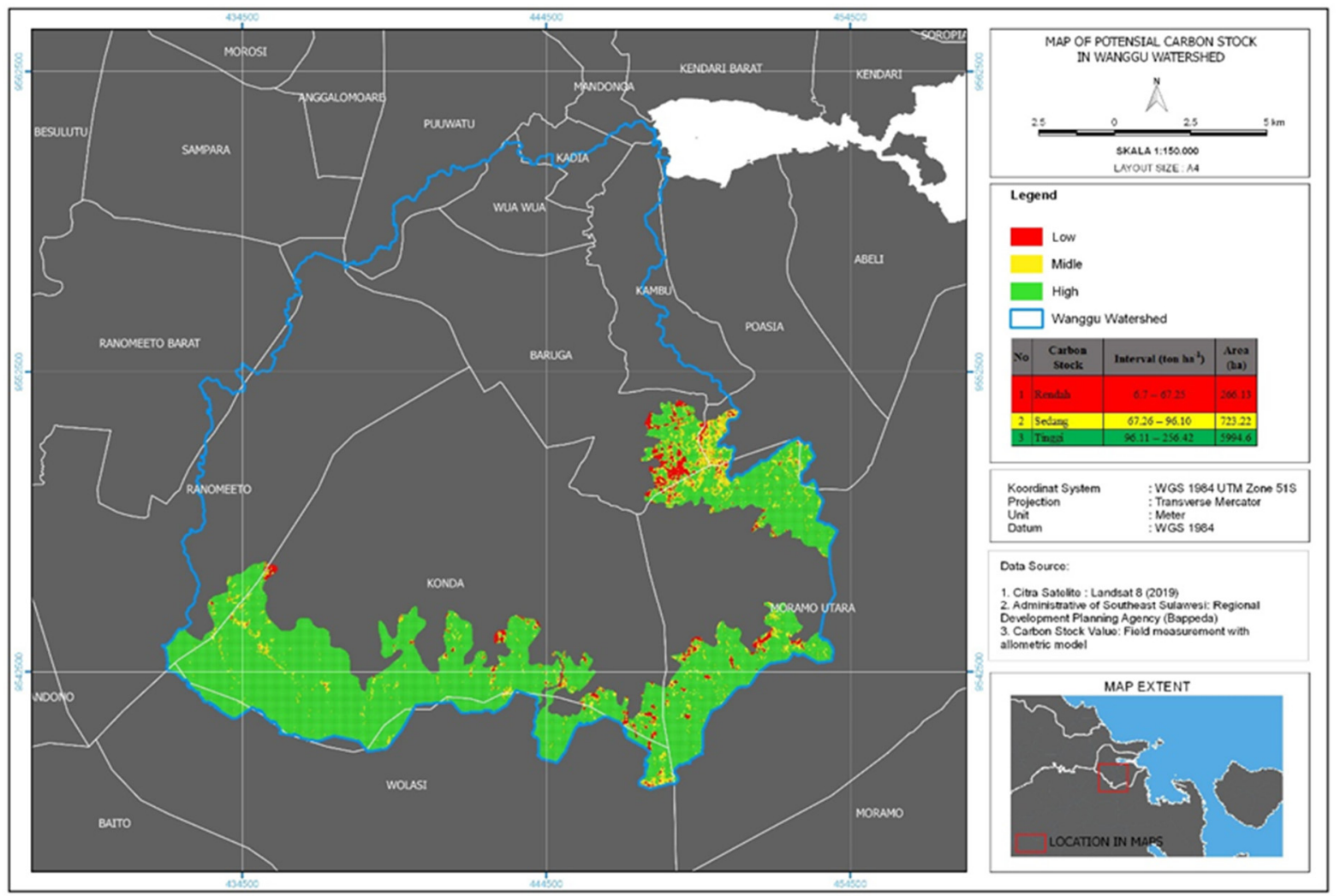

Figure 4. The spatial distribution of carbon stocks in upland forest areas in the Wanggu watershed

The use of the regression models shows that the value of carbon stock in a forest area has a positive correlation 
with the level of vegetation density and area of forest land cover, the higher the level of vegetation density and the wider land cover in a forest area, the value of carbon stocks will be higher.

\section{Conclusions}

The research finds that the high-density class dominated the upland forests of the Wanggu Watershed which covers $6,551.43$ ha or $93.81 \%$ of the total area, followed by medium and low-density classes with an area of 341.64 ha $(4.89 \%)$ and 90.90 ha $(1.30 \%)$ respectively. The estimated stored carbon values using the allometric equation reaches 529,541.01 tons $C$ consisting of 419,197.82 tons $C$ in the protected forests and 110,343.01 tons $C$ in the production forests. The regression analysis shows that the most appropriate model that can be applied to estimate aboveground biomass potential in the upland forests of the Wanggu Watershed is an exponential regression model with the equation $y=3.48$ (Exp. 7,435x). Applying this model, an estimation of aboveground carbon potential in the upland forests of the Wanggu Watershed reaches 414,043.26 tons in 2019 consisting of protected forests of $279,070.15$ tons and production forests of $134,973.11$ tons.

\section{Acknowledgments}

Our gratitude goes to the Rector of Halu Oleo University for the financial support sourced from the Halu Oleo University Budget Implementation List (DIPA) for the Fiscal Year 2019. The special thanks are also delivered to The Head of Research and Community Service Institution (LPPM) and all staff that have facilitated the research administration process. Thank you also to the government of South Konawe District, Ranomeeto, Moramo, and Konda Sub-District of Southeast Sulawesi Province for their cooperation. Our appreciation is given to the Village Heads and Village Communities in Konawe Selatan Regency for their willingness to become partners so that the research runs smoothly and well.

\section{References}

Badan Standardisasi Nasional. (2011). Pengukuran dan penghitungan cadangan karbon-pengukuran lapangan untuk penaksiran cadangan karbon hutan. Jakarta: SNI 7724: 2011.

Chairul, Muchktar, E., Maideliza, T., \& Indra, G. (2016). Struktur kerapatan vegetasi dan estimasi kandungan karbon pada beberapa kondisi hutan di pulau Siberut Sumatera Barat. METAMORFOSA Journal of Biological Sciences, 3(1), 15-22. https://doi.org/10.24843/metamorfosa.2016.v03.i01.p03.

Draper, N. R., \& Smith, H. (1992). Applied regression analysis: second edition. New York: John Wiley and sons, Inc.

Efendi, M., Sunoko, H. R., \& Sulistya, W. (2012). Kajian kerentanan masyarakat terhadap perubahan iklim berbasis daerah aliran sungai (studi kasus Sub Das Garang Hulu). Jurnal Ilmu Lingkungan, 10(1), 8-18. https://doi.org/10.14710/jil.10.1.8-18

Food and Agriculture Organization of the United Nations (FAO). (2006). Global forest resources assessment 2005: Progress towards sustainable forest management. Rome: FAO Forestry Paper 147. FAO.

Green, E. P., Mumbay, P. J., Edwards, A. J., \& Clark, C. D. (2000). Remote sensing hand book for tropical coasta management. Unesco Publishing.

Hairiah, K., \& Rahayu, S. (2007). Pengukuran karbon tersimpan di berbagai macam penggunaan lahan. Bogor (ID): World Agroforestry Centre, ICRAF Southeast Asia Regional Office.

Hairiah, K., Ekadinata, A., Sari, R. R., \& Rahayu, S. (2011). Pengukuran cadangan karbon: dari tingkat lahan ke bentang lahan, petunjuk praktis, edisi kedua. Bogor: World Agroforestry Centre, ICRAF SEA Regional Office, University of Brawijaya (UB), Malang.

Heriansyah, I. (2005). Potensi hutan tanaman industri dalam mense quester karbon. Jurnal Inovasi On Line. Bogor: Pusat Penelitian dan Pengembangan Hutan dan Koservasi Alam.

Herold, M., \& Skutsch, M., (2009). Measurement, reporting and verification for REDD+: objectives, capacities and institutions. In Dalam: Angelsen, A., Brockhaus, M., Kanninen, M., Sills, E., Sunderlin, W. D., \& Wertz Kanounnik off, S. (Eds.), Realising REDD+: National strategy and policy options (pp. 85-100). Indonesia, Bogor: CIFOR.

Idris, M. H., Latifah, S., Aji, I. M. L., Wahyuningsih, E. I., \& Ningsih, R. V. (2015). Struktur kerapatan vegetasi dan estimasi kandungan karbon pada beberapa kondisi hutan di pulau Siberut Sumatera Barat. METAMORFOSA Journal of Biological Sciences. https://doi.org/10.24843/metamorfosa.2016.v03.i01.p03.

Intergovernmental Panel on Climate Change (IPCC). (2003). Good practice guidance for land use, land-use change and forestry. Hayama (JP): The Institute for Global Enviromental Strategies (IGES). 
Kasim, S., \& Midi, L. O. (2014). Desain agroforestry sebagai tindakan konservasi vegetatif untuk pengelolaan DAS Baubau berkelanjutan. Kendari: LPPM Universitas Halu Oleo.

Kasim, S., Rianse, U., Iswandi, M., \& Kandari, A. M. (2020). Spatial analysis of flooding hazard and it's implication to watershed ecosystem resilience (a case study from Wanggu watershed eastern Indonesia). Global Journal of Engineering Science and Researches, 7(2).

Ketterings, Q. M., van Noordwijk, R. C., Ambagau, M., \& Palm, C. (2001). Reducing uncertainly in the use of allometric biomass equation for predicting above-ground tree biomass in mixed secondary forest. Forest Ecology and Management, 146, 199-209. https://doi.org/10.1016/S0378-1127(00)00460-6

Marispatin, N., Ginoga, K., Pari, G., Dharmawan, W. S., Siregar, C. A., Wibowo, A., Lugina, M. (2010). Cadangan karbon pada berbagai tipe hutan dan jenis tanaman di Indonesia. Bogor: Pusat Penelitian dan Pengembangan Perubahan Iklim dan Kebijakan.

Meneses-Tovar, C. L. (2011). NDVI as an indicator of degradation. Unasylva, 62(238), 39-46.

Standar Nasional Indonesia (SNI). (2011). Pengukuran dan perhitungan cadangan karbon-pengukuran lapangan untuk penaksiran cadangan karbon hutan. Jakarta (ID): Badan Standardisasi Nasional.

Suyadi, Ulumudin, Y. I., \& Vebriansyah, R. (2013). Indeks Vegetasi dari Citra Satelit ALOS untuk memperkirakan cadangan karbon atas permukaan di hutan mangrove. Berita Biologi, 12(2), 249-258.

Syam'ani, Agustina, A. R., Susilawati, \& Nugroho, Y. (2012). Cadangan karbon di atas permukaan tanah pada berbagai sistem penutupan lahan di sub-sub DAS Amandit. Jurnal Hutan Tropis. https://doi.org/10.20527/jht.v13i2.1531

Wahyuni, S. (2016). Estimasi cadangan karbon di atas permukaan tanah di Hutan Bukit Tangah Pulau Area Produksi PT. Kencana Sawit Indonesia (KSI), Solok Selatan. Bio-Lectura, 3(1), https://doi.org/10.31849/bl.v3i1.332

Walpole, R. E. (1995). Pengantar statistika: Volume ke-3. Sumantri B, penerjemah, terjemahan dari: introduction to statistics (3rd ed.). Jakarta (ID): Gramedia Pustaka Utama.

Wijayadi, S. A. (2017). Analisis cadangan karbon pada Vegetasi Mangrove di Segera Anakan Kabupaten Cilacap Menggunakan Citra Satelit SPOT 6 (skripsi yang tidak dipublikasikan. Institut Pertanian Bogor (IPB). Bogor.

Windarni, C. (2017). Estimasi karbon tersimpan pada hutan mangrove diDesa Margasari Kecamatan Labuhan Maringgai Kabupaten Lampung Timur. Bandar Lampung: Fakultas Pertanian, Universitas Lampung.

\section{Copyrights}

Copyright for this article is retained by the author(s), with first publication rights granted to the journal.

This is an open-access article distributed under the terms and conditions of the Creative Commons Attribution license (http://creativecommons.org/licenses/by/4.0/). 